\title{
IZABELA GATKOWSKA
}

\section{Konotacje koloru w testach swobodnych skojarzeń słownych w ciągu pięćdziesięciu lat. Studium porównawcze}

\section{Wprowadzenie}

Kolor stanowi istotną cechę obiektu fizycznego postrzeganą przez człowieka dzięki najważniejszej ludzkiej percepcji, jaką jest percepcja wzrokowa. Nie będziemy opisywać fizjologicznego procesu percepcji barw z istotnym udziałem siatkówki oka i ludzkiego mózgu, bo choć jest to interesujący proces, to analiza tej zdolności ludzkiej wykracza poza zakres niniejszego tekstu. Mimo że postrzeganie kolorów przez człowieka jest zdolnością uniwersalną, kolor i jego nazywanie różnie się przekłada na struktury językowe w różnych językach, co prowadzi do wniosku, że kolor nie jest pojęciem uniwersalnym (Wierzbicka, 1999, 2011, 19-20). Jednak leksyka nazywająca kolory wchodzi w skład systemu leksykalnego, co pozwala badać strukturę systemu kolorów oraz uwarunkowane kulturowo i emocjonalnie konotacje leksyki należącej do systemu.

Jedną z uznanych metod badania systemu leksykalnego jest metoda eksperymentalna. Przedstawioną w tym tekście analizę oprzemy na wynikach uzyskanych za pomocą mającego już ponad stuletnią tradycję eksperymentu swobodnych skojarzeń słownych Kent i Rosanoffa (1910), w którym osoba badana podaje pierwszy wyraz, jaki przychodzi jej na myśl po zrozumieniu wyrazu-bodźca. Badania polskiego systemu leksykalnego oparte na liście Kent-Rosanoffa przeprowadzono w odstępie pięćdziesięciu lat: Kurcz (1967), Gatkowska (2017). Lista zawiera sto leksemów-bodźców, a wśród nich nazwy kolorów: biały, żólty, czarny, czerwony, niebieski i zielony. Kolory wybrane przez Kent i Rosanoffa (1910) to podstawowe i kluczowe kolory w kulturze, na co wskazywali Berlin i Kay (1969) i z czym później zgodzili się Saunders i van Brakel (2002)1 . Można

1 „Powstała »przestrzeń« ma trzy wymiary: odcień (lub barwa), nasycenie (lub »czystość«) i wyrazistość (jasność, wartość lub intensywność), a (w niektórych wersjach) jest dodatkowo uporządkowana przez prymitywne lub podstawowe »kolory« - zwykle cztery lub sześć (gdy białe i czarne są dodane do czerwonego, żółtego, zielonego i niebieskiego)" [tłum. I.G.]. 
więc przyjąć, że zestaw kolorów użytych w eksperymencie stanowi wiarygodną podstawę analizy.

\section{Eksperymentalne badanie systemu leksykalnego}

Eksperyment swobodnych skojarzeń słownych, w którym badany podaje pierwszy wyraz, jaki przychodzi na myśl po zrozumieniu wyrazu-bodźca, przynosi w rezultacie zbiór par bodziec - odpowiedź. Liczba par uzyskanych dla konkretnego leksemu-bodźca jest zależna od liczby badanych osób, np. przy 100 badanych ok. 50 par, a przy 1000 badanych ponad 150. Każdej parze bodziec - odpowiedź można przypisać eksperymentalnie uzyskaną siłę powiązania, przedstawianą jako stosunek liczby badanych, którzy udzielili konkretnej odpowiedzi, do liczby wszystkich badanych, np. 50/1000. Jednak z punktu widzenia modelowania systemu leksykalnego istotna jest - niezależna od siły powiązania - jakościowa analiza zależności pomiędzy leksemem-bodźcem i leksemem-odpowiedzią. Ponawiane przez ponad 50 lat coraz bardziej szczegółowe analizy zależności bodziec - odpowiedź (Deese, 1965; Clark, 1970; Gatkowska, 2017) pokazują, że eksperyment przede wszystkim generuje pary, których człony wchodzą $\mathrm{w}$ relacje paradygmatyczne, tj. hiponimię, np. dom - budynek, meronimię, np. dom dach, komplementarność, np. mężczyzna - kobieta, antonimię, np. złość - radość, synonimię, np. kłopot - problem, oraz w różne relacje syntagmatyczne, np. krzesło stół, rzeka - głęboka, góra - wysoka $a^{2}$, a także w różnorodne zależności pragmatyczne, np. ksiądz - pedofil. Ponadto człony par tworzą wielosegmentowe jednostki leksykalne, np. dom - rodzinny, i są składnikami idiomów, np. igła - siano. Są wreszcie nieliczne pary, których człony wiąże podobieństwo brzmieniowe, np. kwiecie - dziecię.

Jeśli więc przyjmiemy za Lyonsem, że struktura semantyczna każdego systemu wyrazów w słowniku jest siecią zbudowaną z relacji semantycznych zachodzących pomiędzy wyrazami należącymi do systemu, to możemy powiedzieć, że skojarzenia uzyskane eksperymentalnie dobrze odwzorowują strukturę systemu leksykalnego ${ }^{3}$.

Pod koniec XX wieku Church i Hanks opracowali algorytm, który generuje pary skojarzeń na podstawie częstości współwystępowania par wyrazów w korpusie tekstów ${ }^{4}$. Algorytm interpretuje dane w obrębie mechanicznie wybieranego okna, liczącego $n$ wyrazów. Rozmiar okna decyduje o jakości wyników: okno mniejsze pozwala na wyekstrahowanie par tworzących stałe struktury, a okno o większym rozmiarze ekstrahuje powiązania o luźnym charakterze. Eksperymenty przeprowadzone dla okna liczącego pięć wyrazów na bardzo dużych korpusach tekstów pokazały, że algorytm ekstrahuje

${ }^{2}$ Wszystkie przykłady pochodzą z cyklicznego eksperymentu przedstawionego w monografii Gatkowska, 2017.

3 „As the most general statement of what is meant by semantic structure - a statement which applies to all words, whether they refer to object and features of the physical world or not - we may adopt the following formulation: the semantic structure of any system of words in the vocabulary is the network of semantic relations that hold between the words in the system in question" (Lyons, 1968, s. 58-59).

4 To znaczy, że algorytm porównuje prawdopodobieństwo współwystąpienia dwu wyrazów z prawdopodobieństwem wystąpienia każdego z nich oddzielnie (por. Church, Hanks, 1990). 
pary tworzące: zestawienia stałe (kolokacje), np. drink driving (jazda po pijanemu), wielosegmentowe jednostki leksykalne, np. computer scientist (informatyk), człony relacji semantycznej, np. man woman (mężczyzna kobieta), wyrażenia gramatyczne, np. coming from (pochodzić z). Zdaniem autorów przyjęty przez nich sposób generowania skojarzeń jest bardziej obiektywny i zdecydowanie tańszy niż eksperyment swobodnych skojarzeń słownych.

Porównanie skojarzeń uzyskanych za pomocą eksperymentu psycholingwistycznego ze skojarzeniami generowanymi automatycznie za pomocą różnych algorytmów (Rapp, 2002; Korzycki i in., 2017) pokazuje, że skojarzenia generowane z tekstów mimo pewnych podobieństw nie odwzorowują w pełni skojarzeń uzyskanych w wyniku eksperymentu swobodnych skojarzeń słownych. Dlatego w naszej analizie kolorów użyjemy wyników eksperymentu psycholingwistycznego.

\section{Dobór materiału językowego}

Materiał językowy wykorzystany do analizy pochodzi z badań skojarzeniowych wykonanych na dużych grupach uczestników, którymi byli studenci. Pierwsze z badań przeprowadziła w latach 1964-1965 na grupie 1000 warszawskich studentów Ida Kurcz. Wykorzystała przetłumaczoną na język polski listę Kent i Rosanoffa. Na liście znalazło się 100 bodźców, a wśród nich wystąpiły następujące nazwy kolorów: biały, żółty, czarny, czerwony, niebieski i zielony. W wyniku eksperymentu powstały listy skojarzeniowe, tj. zbiór par bodziec - odpowiedź. Drugie badanie to przeprowadzony w latach 2011-2014 na grupie 900 krakowskich studentów tzw. cykliczny eksperyment skojarzeń słownych, w którym w funkcji bodźców użyto 63 leksemów z listy Kent i Rosanoffa i po 5 najczęstszych odpowiedzi dla każdego z 63 leksemów-bodźców uzyskanych w eksperymencie Kurcz.

W rezultacie większość bodźców była charakteryzowana przez dwa zbiory par, tj. pary, w których konkretny leksem był bodźcem (powiązania wychodzące $A \rightarrow B$ ), oraz pary, w których ten sam leksem był odpowiedzią (powiązania przychodzące $A \leftarrow B$ ). Sieć leksykalna uzyskana w wyniku eksperymentu liczy ponad 8000 leksemów (Gatkowska, 2017). Reprezentacja leksykalna kolorów w eksperymencie cyklicznym jest bogatsza, gdyż w drugim cyklu jako bodźce wykorzystano nazwy kolorów: biały, żółty, czarny, które były odpowiedziami w eksperymencie Kurcz. Pozostałe nazwy kolorów: czerwony, niebieski i zielony nie były bodźcami w eksperymencie, były tylko odpowiedzią do innych bodźców. Fakt, że w wyniku eksperymentu cyklicznego leksem-bodziec uzyskuje bogatszą charakterystykę, nie przeszkadza w porównywaniu wyników obu eksperymentów, bowiem pary leksemów łączonych przez powiązania wychodzące i przychodzące produkuje ten sam mechanizm psycholingwistyczny.

\section{Kolor w eksperymentalnie modelowanym systemie leksykalnym}

W systemie leksykalnym leksemy reprezentujące kolor tworzą strukturę, którą można nazwać skalą, gdzie kolory są uporządkowane według stopnia jasności, a skrajne 
wartości skali wchodzą w relację antonimii: biały - czarny. Poszczególnym elementom skali przysługują relacje funkcjonalne ujawniające się w połączeniu z obiektem. Konkretny kolor (element skali) może być cechą inherentną obiektu, np. zielona roślina, lub cechą zewnętrzną, tj. nadaną obiektowi z zewnątrz w wyniku wyboru, np. zielona - sukienka, zielona - tawka. Konkretny kolor może także wchodzić w relacje ze stanami, a wówczas jest językowym odbiciem pozajęzykowej konwencji, np. biały niewinność, lub językowym odbiciem stanu emocjonalnego, np. zielony - spokój.

\section{Analiza nazw kolorów}

Przyjrzymy się odpowiedziom uzyskanym do nazw kolorów, które wystąpiły jako bodziec w eksperymencie Kurcz, są nimi: biały, żólty, czerwony, niebieski i zielony, oraz we współczesnym eksperymencie skojarzeniowym (Gatkowska, 2017).

W analizowanych wynikach testów skojarzeniowych, w sytuacji gdy bodźcem była nazwa koloru, możemy zauważyć następujące prawidłowości w zbiorach odpowiedzi:

- do każdego z tych bodźców udzielana jest odpowiedź: kolor, która stanowi określenie kategorii,

- często podawana jest nazwa innego koloru, przykładowo: biały $\leftrightarrow$ żólty ${ }^{5}$, żólty $\rightarrow$ zielony, źólty $\rightarrow$ czarny, czarny $\rightarrow$ niebieski itd.,

- nazwy kolorów w sposób naturalny towarzyszą obiektowi jako cecha inherentna bądź, jak by powiedzieli psycholodzy, jako składnik pojęcia. Zatem oczywiste są odpowiedzi wiążące kolor z obiektem typu: bialy - śnieg, żótty - żonkil, czerwony - owoc, czarny - smoking, zielona - roślina, niebieskie - niebo itd. Tymi naturalnymi zależnościami par: nazwa koloru - odpowiedź nie będziemy się zajmować szczegółowo, gdyż wiążą obiekt z cechą stałą i w efekcie wykazują duży stopień podobieństwa w obydwu testach. Zajmiemy się natomiast tymi powiązaniami, które mogły ulec zmianie, gdyż stanowią językowe odbicie pozajęzykowej konwencji. Omawiać będziemy każdy kolor odrębnie. Najpierw przedstawimy najczęstsze powiązania koloru uzyskane w obydwu eksperymentach. W dalszej kolejności przenalizujemy to, jak emocja wiąże się z kolorem oraz jak kolor wiąże się z osobą. Porównamy wyniki sprzed pół wieku z wynikami współczesnymi. Przesunięcie pięćdziesięciu lat pozwala nam zauważyć stałe połączenia pomiędzy nazwą koloru a emocją czy osobą. Pozwala także zaobserwować zmiany, tzn. nowe współczesne odniesienia, przykładowo kolor czarny zaczyna kojarzyć się z elegancją, zaś kolor zielony z pieniędzmi. Co więcej, zobaczymy, że powiązania odzwierciedlające fakty pozajęzykowe wraz z upływem czasu tracą na znaczeniu (np. sytuacja polityczna Polski w latach 60. XX w. a kolor czerwony). Na zakończenie przedstawimy zbiorczo powiązania kolor - stan i kolor - osoba.

Podane w tekście wartości liczbowe (także liczby w nawiasach) oznaczają liczbę udzielonych odpowiedzi.

\footnotetext{
${ }^{5}$ Symbol $\leftrightarrow$ oznacza powiązanie zwrotne, tj. istnieją dwie pary: $\mathrm{A} \rightarrow \mathrm{B}$ i $\mathrm{B} \rightarrow \mathrm{A}$.
} 


\section{Kolor biały}

W eksperymencie Kurcz na bodziec biały najsilniejsze odpowiedzi to: śnieg (209), czarny (142), dom (73), kanion (48), kolor (48).

We współczesnym badaniu leksem biały był bodźcem, a to oznacza, że w eksperymentalnej sieci jest węzłem pełnym z powiązaniami wychodzącymi, najsilniejsze to: śnieg (181), kolor (111), czarny (79), kruk (43), dom (34), oraz powiązaniami przychodzącymi (leksem biały stanowił odpowiedź): orzeł (137), czarny (131), fartuch (66), ser (47), cukier (39). Zwróćmy uwagę na podobieństwo pomiędzy odpowiedziami, jakie uzyskała Kurcz $(\mathrm{A} \rightarrow \mathrm{B})$, a odpowiedziami uzyskanymi pół wieku później, które w eksperymentalnej sieci są powiązaniami wychodzącymi $(\mathrm{A} \rightarrow \mathrm{B})$.

Kolorowi białemu tradycja chrześcijańska przypisuje niewinność, czystość, inni upatrują czystość śniegu przenoszoną na biel i jest to czystość rozumiana w sensie fizycznym i moralnym jako niewinność (Tokarski, 2004, s. 49-50), co znajduje swoje odbicie w najliczniejszych skojarzeniach uzyskanych w obydwu badaniach.

Patrząc na tabelę, widzimy, że w odpowiedziach zarówno pół wieku temu, jak i współcześnie kolor biały kojarzony jest ze znaczeniami: czysty, czystość, niewinne, niewinność.

We współczesnym badaniu pojawiła się jednostkowa odpowiedź żałoba, którą możemy interpretować, sięgając do innych kultur, tj. starożytnego Egiptu bądź, co bardziej prawdopodobne, do Chin, gdzie biel uważana jest za kolor nieszczęścia, żałoby właśnie, i występuje w trakcie uroczystości pogrzebowych (Jurek, 2011). W psychologicznej koncepcji znaczenia kolorów bieli przypisany jest również spokój, co widzimy w dwóch odpowiedziach eksperymentu Kurcz.

\section{Kolor żólty}

W eksperymencie Kurcz najsilniejszymi odpowiedziami na bodziec żótty są: kolor (163), kwiat (84), Chińczyk (42), ser (41), cytryna (33), zielony (28).

We współczesnym badaniu leksem żółty był bodźcem, a to oznacza, że w eksperymentalnej sieci jest węzłem pełnym z powiązaniami wychodzącymi, najsilniejsze to: ser (347), kolor (179), 0 [odpowiedzi puste] (38), słońce (29), kwiat (28), zielony (22). Zwróćmy uwagę na podobieństwo wyników, jakie dzieli pół wieku. Odpowiedzi puste, które we współczesnym eksperymencie osiągnęły stosunkowo wysoką pozycję, wynikają ze sposobu przeprowadzenia doświadczenia, a mianowicie wykorzystano specjalnie przygotowaną aplikację, która wydobyła rzeczywiste pierwsze naturalne skojarzenia lub ich brak. W eksperymentalnej sieci węzeł pełny ma również powiązania przychodzące $(\mathrm{A} \leftarrow \mathrm{B})$, które dla węzła żółty wyglądają następująco: ser (240), słońce (6), ttuszcz (5), jasny (4), kwiat (4).

Psychologiczne podejście do znaczenia koloru żółtego jest ambiwalentne, tzn. ten kolor może symbolizować zarówno dobro, jak i zło, optymizm, jak i zazdrość. I takie odpowiedzi znalazły się w wynikach sprzed pół wieku, tzn. dominuje zazdrość, pojawia 
się też zdrada oraz leksem złośliwy, współcześnie także pojedyncze odpowiedzi złość oraz zgodnie z trendami w marketingu - optymizm (Nęcki i in., 1999). Wśród przychodzących wystąpiła radość, ze względu na fakt, że jest to kolor słońca, niekiedy nazywany słonecznym, może on budzić radość.

\section{Kolor czarny}

W eksperymencie Kurcz najsilniejsze odpowiedzi na bodziec czarny to: biały (195), kot (152), kolor (77), pies (34), noc (29), Murzyn (26).

We współczesnym badaniu leksem czarny był bodźcem, a to oznacza, że w eksperymentalnej sieci jest węzłem pełnym z powiązaniami wychodzącymi, najsilniejsze to: kolor (151), biaty (131), kot (74), 0 [odpowiedzi puste] (50), chleb (34), Murzyn (28), oraz powiązaniami przychodzącymi (leksem czarny stanowił odpowiedź A $\leftarrow$ B): biały (79), dym (15), dziura (11), kolorowy (11), ksiadz (11).

W naszej kulturze czerń jest oznaką żałoby. I takie też odpowiedzi, żałoba oraz pogrzeb, znalazły się w wynikach badań zarówno pół wieku temu, jak i współcześnie. Równie silnie w obydwu badaniach leksem czarny łączy się ze smutkiem, z zaduma, powaga czy wręcz ze śmiercia, z trumna, końcem.

W psychologii kolor czarny kojarzy się też z tajemnicą, siłą, a także z niebezpieczeństwem, złem. W badaniach Kurcz pojawiły się odpowiedzi: nieznany, nieprzyjemny, a współcześnie w powiązaniach wychodzących tajemniczy, zaś w przychodzących niepokój. Dodatkowo w badaniach Kurcz na bodziec czarny odpowiadano diabet (18), zły (3), ciemność (2), mara (1), piekło (1), zaś we współczesnym doświadczeniu liczna reprezentacja leksykalna powiązań wychodzących to: diabet (3) demon (1), książę (1), krag (1), piekło (2), otchłań (1), wampir (1), zły (1), zło (1), Szatan (1).

W eksperymencie Kurcz pojawiła się odpowiedź pesymista i współcześnie w powiązaniach wychodzących depresja (Nęcki i in., 1999), rzeczywiście osoby cierpiące na depresję mają skłonność do demonstrowania swojego stanu emocjonalnego poprzez czarny strój, a także niekiedy czarne elementy makijażu u kobiet. We współczesnym badaniu wystąpiło powiązanie przychodzące czarny $\leftarrow$ radość, które możemy odczytać w kontekście innych kultur, np. chińskiej (Jurek, 2011). Poza tym w obydwu badaniach występuje wielosegmentowa jednostka leksykalna czarny charakter, w badaniu Kurcz charakter osiąga wartość 21 odpowiedzi, współcześnie (Gatkowska, 2017) wychodzące $\mathrm{A} \rightarrow \mathrm{B}$ (od bodźca czarny) charakter występuje w 11 odpowiedziach. Dodatkowo we współczesnym badaniu znalazły się powiązania przychodzące $(\mathrm{A} \leftarrow \mathrm{B})$ do węzła czarny: bandyta (4), złodziej (2). Są jeszcze wielosegmentowe jednostki leksykalne, które występują współcześnie, a brak ich w badaniu sprzed pół wieku, tj.: czarny tabędź (15), czarny humor (4), czarny PR (1), czarny chleb i czarna kawa (1) oraz, co ciekawe, czarna owca (5), w badaniu Kurcz jest czarny baran (7). W obydwu badaniach pojawia się czarny Piotruś - współcześnie wśród powiązań wychodzących (1), a w badaniu Kurcz (3). 
Współcześnie podkreśla się, że w XX w. kolor czarny stał się kolorem elegancji, szyku, i rzeczywiście znalazła się nowa reprezentacja tego znaczenia, współcześnie: powiązanie wychodzące $(\mathrm{A} \rightarrow \mathrm{B})$ elegancki, w badaniu sprzed pół wieku nieistniejące.

\section{Kolor czerwony}

Kolor czerwony stereotypowo kojarzony jest z kolorem krwi, miłości, ale i nienawiści, namiętności. Psycholodzy zwracają uwagę, że ten kolor budzi w ludziach także postawy agresywne. W badaniu Kurcz najsilniejsza reakcja wystąpiła z leksemem sztandar (108), następnie kolor (99), czarny (74), kapturek (66), tworząc wielosegmentową jednostkę leksykalną, podobnie jak mak(i) (64), a w dalszej kolejności krew (31). Miłość czy namiętność bezpośrednio jest nieobecna. We współczesnym badaniu leksem czerwony nie był bodźcem, stąd w sieci eksperymentalnej jest węzłem zredukowanym i mamy tylko powiązania przychodzące $(\mathrm{A} \leftarrow \mathrm{B})$, najsilniejsze z nich to: dywan (8), złość (7), kwiat (6), róża (6).

W obydwu badaniach mamy połączenie koloru czerwonego ze stanami nazywającymi emocje - współcześnie: złość, zły, gniew, nerwy, w badaniu sprzed pół wieku pojedyncze wstręt, wstrętny (być może to ocena koloru dokonana przez uczestnika badania), oraz współcześnie oznakę emocji złość, jak krzyk. Współcześnie wystąpiło pojedyncze powiązanie z radością, z tą emocją również kolor czerwony bywa kojarzony w psychologii. W obydwu eksperymentach pojawia się pośredni symbol miłości, tzn. występuje połączenie czerwony - róża (IK 4), współcześnie powiązanie przychodzące o sile 6, oraz czerwony - kwiat (IK 26, IG 6), u Kurcz dodatkowo goździk (4).

W eksperymencie Kurcz bodziec czerwony uzyskał odpowiedzi: ogień (13), płomień (4), co potwierdza obserwację Tokarskiego ${ }^{6}$, piekło (1), wąż (2), żar (2). W badaniu Kurcz wystąpiła też wielosegmentowa jednostka leksykalna: czerwony - krzyż (12), PCK (1). Czerwony jest także kolorem ostrzegawczym, w badaniu Kurcz: sygnat (7), żółty (5), zielony (31), alarm (1), współcześnie powiązania przychodzące (A ty (2), światło (1). Z pewnością obydwa eksperymenty różni bogata pragmatyczna reprezentacja skojarzeń z ówczesną sytuacją polityczną Polski rządzonej przez komunistów, obecnością czerwonych flag, napisów propagandowych zdominowanych przez czerwień itd. (nieobecna we współczesnej sieci), a więc wyniki uzyskane do bodźca czerwony przez Kurcz: sztandar (108), flaga (12), ZSRR (5), choragiew (3), komunizm (3), komunista (2), plac (2), proporzec, proporczyk (2), oraz pojedyncze: maszt, pałac, partia, radziecki, rewolucja, robotnik, strajk, święto, znak.

Interesujące wydają się hiszpańskie odniesienia do koloru czerwonego występujące w doświadczeniu Kurcz: Corrida (2), płachta (na byka) (4), Flamanco ${ }^{7}$ (1).

6 „Prototypem dla barwy czerwonej jest również świeża, jasna krew oraz płonący ogień czy może raczej żarzący się węgiel” (Tokarski, 2004, s. 80).

7 Zachowana pisownia oryginalna. 


\section{Kolor niebieski}

Z perspektywy psychologii to kolor harmonii, wierności i współczucia. W neuromarketingu uważa się, że niebieski poprawia produktywność, ułatwia skupienie, z tego więc powodu chętnie wykorzystywany jest w biurach. To kolor, który buduje zaufanie do marki i sugeruje poczucie pewności. Mimo że to najzimniejsza barwa, jest związana z pojęciem duchowości i fantazji. Po tym kognitywnym wprowadzeniu zobaczmy, od jakich najczęstszych odpowiedzi rozpoczyna się lista eksperymentu Kurcz: (jak) niebo (179), ptak (162), kolor (121), czarny (34), oko (28), atrament (24). We współczesnym badaniu leksem niebieski nie był bodźcem, stąd w sieci eksperymentalnej jest węzłem zredukowanym i mamy tylko powiązania przychodzące $(A \leftarrow B)$, najsilniejsze z nich to: ocean (16), ptak (6), zólty (6), spokojny (4), woda (4). W eksperymencie Kurcz kolor niebieski określany jest jako zimny, w obydwu doświadczeniach występuje połączenie niebieski - spokój, współcześnie jeszcze powiązanie z nerwy, zaś w badaniu Kurcz łagodność i niewinność, co może wynikać z interpretowania go jako koloru szat anielskich (Jurek, 2011).

\section{Kolor zielony}

Kolor zielony zdaniem psychologii to kolor wzrostu, odnowy i odrodzenia, często kojarzony ze zdrowiem, naturą, świeżością i spokojem. Podobno pomaga w rozwiązywaniu problemów i promuje wolność, uzdrowienie, umożliwia zrelaksowanie się (dlatego jest zalecany chorym na depresję) i daje spokój. Współcześnie podkreśla się, że ciemna zieleń reprezentuje pieniądze, sprawy gospodarcze i burżuazję. Po tym psychologicznym wstępie zobaczmy, jak kształtowały się najmocniejsze odpowiedzi dla bodźca zielony w badaniu Kurcz: kolor (97), trawa (97), las (96), liść (96), stót (42). We współczesnym badaniu leksem zielony nie był bodźcem, stąd w sieci eksperymentalnej jest węzłem zredukowanym i mamy tylko powiązania przychodzące $(\mathrm{A} \leftarrow \mathrm{B})$, najsilniejsze $\mathrm{z}$ nich to: liść (95), żółty (22), roślina (9), pieniądz (8), mundur (7).

Analizując nazwę koloru zielonego w kontekście przypisanej mu emocji, widzimy, że w badaniu Kurcz najsilniej reprezentowana jest nadzieja, następnie w obydwu badaniach pojawia się odpowiedź spokojny oraz spokój (IK). Możemy zaobserwować, że w badaniu sprzed pół wieku zieleń symbolizuje brak doświadczenia, co reprezentują pojedyncze odpowiedzi: głupi, dureń, niedoświadczony, niezorientowany. Pojawiają się odpowiedzi oceniające: przyjemność, przyjemny, a także najwyraźniej odnoszące się do wyglądu, jak blady, bladość i wreszcie zazdrość; ta odpowiedź wydaje się częścią wielosegmentowej jednostki leksykalnej: zzielenieć z zazdrości ${ }^{8}$. Spośród innych ciekawych

8 „Zzielenieć »2. O ludziach: zblednąć tak, że cera nabiera zielonkawego odcienia, pozielenieć« Zzielenieć ze strachu, ze złości, żart. z zazdrości”, Stownik języka polskiego pod red. M. Szymczaka, PWN, 1981, T. III, s. 1079-1080. 
odpowiedzi w badaniu Kurcz na bodziec zielony: odpowiedź sygnał (3). Współcześnie występuje pojedyncze powiązanie z węzłem radość. Natomiast uwagę zwraca dość silne powiązanie przychodzące $(\mathrm{A} \leftarrow \mathrm{B}) \mathrm{z}$ węzła pieniądz $(8)$, które nie występuje w badaniu sprzed pół wieku, a które w psychologiczno-marketingowym kontekście oznacza, że kolor zielony reprezentuje pieniądz.

\section{Zależności kolor - stan}

Poniższa tabela przedstawia zależności pomiędzy nazwą koloru a przypisanym danemu kolorowi stanem (emocji lub postawie). Podane wartości oznaczają liczbę udzielonych odpowiedzi.

\begin{tabular}{|c|c|c|}
\hline $\begin{array}{l}\text { IK (1967) } \\
\quad \mathrm{A} \rightarrow \mathrm{B}\end{array}$ & $\begin{array}{c}\text { IG (2017) } \\
\text { wychodzące } A \rightarrow B\end{array}$ & $\begin{array}{c}\text { IG (2017) } \\
\text { przychodzące } A \leftarrow B\end{array}$ \\
\hline $\begin{array}{l}\text { Biały czysty } 7 \text {, niewinne } 1 \text {, } \\
\text { niewinność } 1 \text {, radość } 1 \text {, spo- } \\
\text { kojność } 1 \text {, spokojny } 1\end{array}$ & $\begin{array}{l}\text { Biały niewinność } 8 \text {, } \\
\text { czystość } 6 \text {, niewinny } 2 \text {, szczęś- } \\
\text { liwy } 1 \text {, szlachetny } 1 \text {, żałoba } 1\end{array}$ & Biały brak powiązań \\
\hline $\begin{array}{l}\text { Żólty zazdrość } 19, \text { zdrada } 5 \text {, } \\
\text { złośliwy } 1\end{array}$ & Żólty złość 1 , optymizm 1 & Żólty radość 1 \\
\hline $\begin{array}{l}\text { Czarny żałoba } 9 \text {, zły } 3, \\
\text { pogrzeb } 2 \text {, śmierć } 2 \text {, smutek } 2, \\
\text { chłód } 1 \text {, ciepły } 1 \text {, nieznany } 1, \\
\text { nieprzyjemny } 1 \text {, pesymista } 1, \\
\text { żałobny } 1 \text {, zaduma } 1\end{array}$ & $\begin{array}{l}\text { Czarny śmierć } 6 \text {, smutek } 5 \text {, } \\
\text { humor } 4 \text {, żałoba } 5 \text {, elegancki } 2 \text {, } \\
\text { pogrzeb } 1 \text {, ponury } 1 \text {, depresja } 1 \text {, } \\
\text { poważny } 2 \text {, radość } 1 \text {, smutny } 1 \text {, } \\
\text { tajemniczy } 1\end{array}$ & Czarny niepokój 1 , smutek 1 \\
\hline $\begin{array}{l}\text { Czerwony ostry } 2 \text {, szczery } 1 \text {, } \\
\text { wstręt } 1 \text {, wstrętny } 1 \text {, zły } 1\end{array}$ & & $\begin{array}{l}\text { Czerwony złość } 7 \text {, gniew } 2 \text {, } \\
\text { krzyk } 1 \text {, nerwy } 1 \text {, radość } 1\end{array}$ \\
\hline $\begin{array}{l}\text { Niebieski zimny } 20 \text {, spokój } 4 \text {, } \\
\text { łagodność } 1 \text {, niewinność } 1\end{array}$ & & $\begin{array}{l}\text { Niebieski spokojny } 4, \\
\text { nerwy } 1\end{array}$ \\
\hline $\begin{array}{l}\text { Zielony nadzieja } 5 \text {, spokojny } 2, \\
\text { bladość } 1 \text {, blady } 1 \text {, głupi } 1, \\
\text { dureń } 1 \text {, niedoświadczony } 1, \\
\text { niezorientowany } 1, \\
\text { przyjemność } 1 \text {, przyjemny } 1, \\
\text { spokój } 1 \text {, zazdrość } 1\end{array}$ & & Zielony radość 1 , spokojny 1 \\
\hline
\end{tabular}

Tab. 1. Opracowanie własne.

Emocje stanowią istotną część ludzkiego funkcjonowania, towarzyszą człowiekowi nieustannie, choć nie zawsze są na tyle intensywne, że zostają uświadomione przez człowieka. Możemy dać wyraz emocjom w sposób bezpośredni poprzez reakcje afektywne. Wyrażanie stanów emocjonalnych za pomocą odpowiednich kolorów jest głęboko wpisane w naszą kulturę i tradycję. Zobaczyliśmy, jakie reakcje werbalne wywołały poszczególne omawiane kolory. 


\section{Zależności kolor - osoba}

$\mathrm{Z}$ badawczego punktu widzenia interesujące wydaje się spojrzenie na te powiązania nazw kolorów, które łączą się z osobami. Przyjrzyjmy się poniższej tabeli. Podane wartości liczbowe oznaczają liczbę udzielonych odpowiedzi.

\begin{tabular}{|l|l|l|}
\hline \multicolumn{1}{|c|}{$\begin{array}{c}\text { IK (1967) } \\
\mathbf{A \rightarrow B}\end{array}$} & \multicolumn{1}{|c|}{$\begin{array}{c}\text { IG (2017) } \\
\text { wychodzące A } \rightarrow \mathbf{B}\end{array}$} & \multicolumn{1}{c|}{$\begin{array}{c}\text { IG (2017) } \\
\text { przychodzące A } \leftarrow \text { B }\end{array}$} \\
\hline Biały człowiek 2 & Biały człowiek 3, mężczyzna 3 & $\begin{array}{l}\text { Biały lekarz 4, doktor 4, czło- } \\
\text { wiek 3, mężczyzna 1 }\end{array}$ \\
\hline $\begin{array}{l}\text { Żólty Chińczyk 42, } \\
\text { człowiek 2, mandaryn 2, } \\
\text { Azja 1, Chiny 1, rasa 1 }\end{array}$ & Żólty Chińczyk 9, Japonia 1 & Żólty brak powiązań \\
\hline $\begin{array}{l}\text { Czarny Murzyn 26, komi- } \\
\text { niarz 4, człowiek 3, chłopiec 2, } \\
\text { Afryka 1, karawaniarz 1 }\end{array}$ & $\begin{array}{l}\text { Czarny Murzyn 28, } \\
\text { człowiek 4, ksiądz 4 }\end{array}$ & $\begin{array}{l}\text { Czarny ksiądz 11, człowiek 3, } \\
\text { proboszcz 2, duchowny 1 }\end{array}$ \\
\hline Czerwony brak powiązań & & Czerwony pijak 1 \\
\hline Niebieski ptak 162 & & Niebieski ptak 6, chłopiec 3 \\
\hline $\begin{array}{l}\text { Zielony człowiek 3, } \\
\text { chłopak 2 }\end{array}$ & & $\begin{array}{l}\text { Zielony mundur 7, wojsko 5, } \\
\text { żołnierz 2, lekarz 1 }\end{array}$ \\
\hline
\end{tabular}

Tab. 2. Opracowanie własne.

Leksem biały w badaniu sprzed pół wieku łączył się jedynie z leksemem człowiek, we współczesnym badaniu to skojarzenie pozostało na podobnym poziomie, a dodatkowo pojawił się leksem mężczyzna, i to zarówno jako powiązanie wychodzące, jak i przychodzące. Nowością jest obecność leksemów lekarz i doktor (zapewne w rozumieniu 'lekarz medycyny'), gdzie biały jest metonimią przywołującą kolor fartucha lekarskiego. Analogiczna operacja wystąpiła w przypadku leksemu - bodźca czarny, przywołującego kolor sutanny, a więc stroju księdza (dodatkowo w eksperymentalnej sieci leksykalnej mamy powiązania: sutanna - czarny oraz sutanna - ksiądz). Tutaj obserwujemy bogatą reprezentację leksykalną stanu duchownego, albowiem czarny łączy się z leksemami: ksiąd, proboszcz i duchowny, oraz leksemu zielony przywołującego mundur, a także wojsko oraz jego meronim, tj. żotnierza. Podobny mechanizm znacznie skromniej reprezentowany jest w badaniu sprzed pół wieku, gdzie leksem czarny łączy się z leksemami karawaniarz i kominiarz. Natomiast współczesne powiązanie zielony - lekarz należy rozumieć inaczej, tzn. jako osobę niedoświadczoną, podobnie jak w wynikach sprzed pół wieku zielony - człowiek, chłopak. W przypadku połączenia leksemów niebieski ptak $k^{9}$ oznaczający osobę niepracującą, widzimy bardzo silne powiązanie sprzed pół

9 „Niebieski ptak »o człowieku lekkomyślnym, nieodpowiedzialnym, niemającym określonego zajęcia, żyjącym cudzym kosztem; próżniak, darmozjad «", A. Kłosińska, E. Sobol, A. Stankiewicz, Wielki stownik frazeologiczny PWN z przystowiami, Wydawnictwo Naukowe PWN, Warszawa 2005, s. 427. 
wieku, występujące także współcześnie, lecz dużo słabiej reprezentowane. Ten przykład pokazuje, jak zmienia się rozpoznawalność frazeologizmu.

Zaś połączenie niebieski - chłopiec występujące we współczesnym badaniu wydaje się, że wskazuje na stereotypowe łączenie koloru z płcią, szczególnie widoczne w ubiorze i akcesoriach małych dzieci, tzn. dziewczynce przypisany zwyczajowo jest kolor różowy, zaś chłopcu niebieski.

W przypadku leksemu-bodźca czarny w podobny sposób w obydwu badaniach reprezentowany jest 'czarny człowiek', a więc Murzyn, dodatkowo w badaniu Kurcz wystąpiła nazwa kontynentu, tj. Afryka.

Leksem - bodziec żólty pół wieku temu wyraźnie łączył się z Chińczykiem, mandarynem i Chinami, współcześnie także występuje powiązanie z Chińczykiem, jednak jest dużo słabsze; pojawiła się też Japonia. Dodatkowo we współczesnym badaniu leksem czerwony został połączony z leksemem pijak, co zapewne wynika z obserwacji stereotypowych cech osób nadużywających alkoholu.

\section{Zakończenie}

Słownik języka naturalnego jest siecią zbudowaną z relacji semantycznych zachodzących pomiędzy leksemami należącymi do tegoż systemu leksykalnego (Lyons, 1968). Psycholingwistyczny eksperyment swobodnych skojarzeń słownych pozwala zbudować empiryczny model takiej sieci. Jednak sieć zbudowana eksperymentalnie oprócz relacji semantycznych zawiera także powiązania (skojarzenia) umotywowane konwencjami lub faktami pozajęzykowymi, które mogą się zmieniać niezalenie od systemu leksykalnego. Nazwy kolorów tworzą podsystem leksykalny szczególnie związany z konwencjami i faktami pozajęzykowymi.

Tematem artykułu była analiza zależności leksykalnych, w jakie w sposób empiryczny, ujawniony dzięki mechanizmowi skojarzeniowemu, wchodzą leksemy reprezentujące nazwy kolorów. Porównano wyniki dwóch eksperymentów badania swobodnych skojarzeń słownych przeprowadzonych na licznych grupach studentów, które dzieli pięćdziesiąt lat (Kurcz, 1967; Gatkowska, 2017). Porównując wyniki, mogliśmy zaobserwować oczekiwaną stałość zależności semantycznych, wynikającą z faktu, że dany kolor stanowi cechę inherentną obiektu (np. biały - śnieg). Zmian można było oczekiwać w analizie zależności umotywowanych przez konwencje i fakty pozajęzykowe. Jednak analiza pokazuje, że w przypadku pewnych konwencji pozajęzykowych odległość pięćdziesięciu lat nie wnosi znaczących zmian. Przykładowo kolor biały kojarzył się i nadal się kojarzy z czystością, niewinnością. Podobnie często utrzymuje się znaczenie symboliki nazwy koloru z emocją czy wydarzeniem (np. zielony - spokojny, czarny - żałoba, pogrzeb, smutek). Również mechanizm łączenia nazwy koloru z osobą cechuje stałość. Różnice dotyczą stopnia nasilenia, przykładowo: żótty $\rightarrow$ Chińczyk 42 (1967), żólty $\rightarrow$ Chińczyk 9 (2017), a niekiedy profesji, przykładowo: czarny $\rightarrow$ kominiarz 4 (1967), czarny $\rightarrow$ ksiadz 4 (2017), czarny $\leftarrow k s i a d z$ 11(2017).

Natomiast wyraźne zmiany możemy zaobserwować w przypadku powiązań determinowanych przez fakty pozajęzykowe. Dobrą ilustrację zmiany stanowi kolor czerwony, 
który w badaniu Kurcz był silnie związany z symboliką używaną przez system ideologiczno-politycznym ówczesnej Polski, a powiązań tego typu brak w badaniu współczesnym. I odwrotnie, badanie współczesne pokazuje zależności nieobecne w badaniu wcześniejszym, np. czarny - elegancja, zielony - pieniądz.

Porównanie zależności, w jakie wchodzą nazwy kolorów, pokazuje także różnice w rozpoznawalności frazeologizmów, np. silne powiązanie niebieski - ptak w badaniu Kurcz traci swoją moc w badaniu współczesnym.

Można więc powiedzieć, że analiza powiązań nazw kolorów ujawnionych w obu eksperymentach pozwala stwierdzić, iż system leksykalny wykazuje stabilność zależności determinowanych przez konwencje, lecz jest podatny na zmiany związane z faktami pozajęzykowymi.

\section{Bibliografia}

Berlin, B., Kay, P. (1969). Basic Color Terms: Their Universality and Evolution. Berkeley: University of California Press.

Church, K.W., Hanks, P. (1990). Word Association Norms, Mutual Information, and Lexicography, Computational Linguistics, 16(1), s. 22-29.

Clark, H.H. (1970).Word Associations and Linguistic Theory. W: J. Lyons (red.), New Horizon in Linguistics (s. 271-286). Middlesex: Penguin Books Ltd, Harmondsworth.

Deese, J. (1965). The Structure of Associations in Language and Thought. Baltimore: Johns Hopkins University Press.

Gatkowska, I. (2017). Eksperymentalna sieć leksykalna języka polskiego. Kraków: Wydawnictwo Uniwersytetu Jagiellońskiego.

Jurek, K. (2011). Znaczenie symboliczne i funkcje koloru w kulturze. Kultura, Media, Teologia, 6, s. 68-80.

Kent, G.H., Rosanoff, A.J. (1910). A study of association in insanity. American Journal of Insanity, 67, s. 37-96, 317-390.

Korzycki, M., Gatkowska, I., Lubaszewski, W. (2017). Can Human Association Norm Evaluate Machine-Made Association Lists. W: B. Sharp, F. Sedes, W. Lubaszewski (red.), Cognitive Approach to Natural Language Processing (s. 21-40). London-Oxford: ISTE/ Elsevier.

Kurcz, I. (1967). Polskie normy skojarzeń swobodnych na 100 słów z listy Kent - Rosanoffa. Studia Psychologiczne, VIII, s. 122-255.

Lubaszewski, W., Gatkowska, I. (2013). Struktura semantyczna języka naturalnego. W: I. Gatkowska, W. Lubaszewski (red.), Interfejs dla osób z dysfunkcją wzroku. Model kognitywny i przykład dobrej praktyki (s. 47-106). Kraków: Wydawnictwo Uniwersytetu Jagiellońskiego.

Lyons, J.L. (1968). Introduction to Theorethical Linguistics. Cambridge: Cambridge University Press.

Lyons, J. (red.) (1970). New Horizon in Linguistics. Middlesex: Penguin Books Ltd, Harmondsworth.

Nęcki, Z., Sowa, I., Rosiński, J. (1999). Psychologia reklamy. W: A.S. Barczak, A. Pitrus (red.), Ze świata reklamy. Kraków: Wydawnictwo Uniwersytetu Jagiellońskiego.

Rapp, R. (2002). The Computation of Word Associations: Comparing Syntagmatic and Paradigmatic Approaches. Proceedings of the 19th International Conference on Computational Linguistics, Taipei, vol. 1 (s. 1-7). Stroudsburg: Association for Computational Linguistics.

Saunders, B., Brakel, J. (2002). The Trajectory of Color. Perspectives on Science, 10 (3), s. 302-355. Pobrane z https://www.muse.jhu.edu/article/43328 (20.03.20).

Sharp, B., Sedes, F., Lubaszewski, W. (red.) (2017). Cognitive Approach to Natural Language Processing. London-Oxford: ISTE/ Elsevier. 
Tokarski, R. (2004). Semantyka barw we współczesnej polszczyźnie. Lublin: Wydawnictwo UMCS.

Wierzbicka, A. (1999). Znaczenie nazw kolorów i uniwersalia widzenia. W: A. Wierzbicka, Język-umyst kultura, wybór prac pod red. J. Bartmińskiego (s. 405-449). Warszawa: Wydawnictwo Naukowe PWN.

Wierzbicka, A. (2011). Uniwersalia ugruntowane empirycznie. Teksty Drugie, 1/2, s. 13-30.

\section{Źródło elektroniczne}

https://pieknoumyslu.com/psychologia-koloru-wplyw/ (dostęp: 20.03.20).

\section{STRESZCZENIE}

Słowa kluczowe: test skojarzeń słownych, lista skojarzeniowa, eksperymentalna sieć leksykalna, nazwy kolorów, stałość semantyczna, stabilność konwencji, zmienność faktów pozajęzykowych.

Artykuł przedstawia analizę danych leksykalnych pozyskanych od 1000 i 900 osób za pomocą eksperymentu skojarzeniowego w dwóch badaniach, które dzieli 50 lat (Kurcz 1967;, Gatkowska 2017). Jako metodę zastosowano analizę porównawczą, której przedmiotem są nazwy kolorów (biały, żółty, czarny, czerwony, niebieski i zielony ) i ich konotacje uzyskane eksperymentalnie. Różnica 50 lat ujawniła stabilność znaczeń (konotacje semantyczne) wynikającą z faktu, że dany kolor stanowi cechę inherentną obiektu (np. biaty śnieg), stabilność konwencji (np. biały - czystość, niewinność) i jednoczesną zmienność faktów pozajęzykowych, np. konotacje bodźca czerwony w badaniu Kurcz motywowane ówczesną sytuacją polityczną Polski, których nie ma w wynikach badania współczesnego, oraz nowe połączenia kolorów (np. czarny - elegancki, zielony - pieniądz). Wspólny jest metonimiczny mechanizm łączenia nazwy koloru z osobą.

\section{SUMMARY}

Color connotations in free word association tests over fifty years. A comparative study.

Keywords: word association test, association list, experimental lexical network, color names, semantic stability, stability of conventions, variability of extra-linguistic facts.

The article presents an analysis of lexical data obtained by a free word association experiment in two studies separated by 50 years (Kurcz 1967, Gatkowska 2017: 1000 and 900 subjects respectively). Comparative analysis was used to analyze the names of colors (white, yellow, black, red, blue and green) and their experimental connotations. The gap of 50 years revealed the stability of meanings (semantic connotations) resulting from the fact that a given color is an inherent feature (e.g. white - snow), as well as stability of conventions (e.g. white - purity, innocence) and the simultaneous variability of extra-linguistic facts, e.g. the numerous lexical connotations of red in the Kurcz study, motivated by the political situation of Poland at the time, that are not present in the contemporary experiment, or new color connotations ( e.g. black - elegant, green - money). In both experiments one can see the use of metonymy to connect a color name and a person. 